\title{
Spermatogonial stem cells from domestic animals: progress and prospects
}

\author{
Yi Zheng ${ }^{1,2,3}$, Yaqing Zhang ${ }^{1,2,3}$, Rongfeng Qu ${ }^{1,2,3}$, Ying $\mathrm{He}^{1,2,3}$, Xiue Tian ${ }^{1,2,3}$ and \\ Wenxian Zeng ${ }^{1,2,3}$ \\ ${ }^{1}$ College of Animal Science and Technology, Northwest A\&F University, Yangling, Shaanxi 712100, China, \\ ${ }^{2}$ Shaanxi Center of Stem Cells Engineering and Technology, Shaanxi, China and ${ }^{3}$ Key Lab for Biotechnology of \\ Agriculture Ministry of China, Shaanxi, China
}

Correspondence should be addressed to W Zeng; Email: zengwnxian@hotmail.com or to X Tian; Email:Txe82@yahoo.com.cn

\begin{abstract}
Spermatogenesis, an elaborate and male-specific process in adult testes by which a number of spermatozoa are produced constantly for male fertility, relies on spermatogonial stem cells (SSCs). As a sub-population of undifferentiated spermatogonia, SSCs are capable of both self-renewal (to maintain sufficient quantities) and differentiation into mature spermatozoa. SSCs are able to convert to pluripotent stem cells during in vitro culture, thus they could function as substitutes for human embryonic stem cells without ethical issues. In addition, this process does not require exogenous transcription factors necessary to produce induced-pluripotent stem cells from somatic cells. Moreover, combining genetic engineering with germ cell transplantation would greatly facilitate the generation of transgenic animals. Since germ cell transplantation into infertile recipient testes was first established in 1994, in vivo and in vitro study and manipulation of SSCs in rodent testes have been progressing at a staggering rate. By contrast, their counterparts in domestic animals, despite the failure to reach a comparable level, still burgeoned and showed striking advances. This review outlines the recent progressions of characterization, isolation, in vitro propagation, and transplantation of spermatogonia/SSCs from domestic animals, thereby shedding light on future exploration of these cells with high value, as well as contributing to the development of reproductive technology for large animals.

Reproduction (2014) 147 R65-R74
\end{abstract}

\section{Introduction}

Spermatogonial stem cells (SSCs) comprise a subpopulation of undifferentiated spermatogonia. Spermatogonia originate from primordial germ cells (PGCs) during embryonic development. In mice, PGCs migrate to the genital ridge at around 10.5 days post coitum, and then they differentiate into gonocytes (Franca et al. 2000). After several days of replication, gonocytes arrest at the cell cycle of $G_{0} / G_{1}$ stage. It is only after birth that gonocytes resuming mitosis gradually migrate from the center to the periphery of seminiferous tubules, with the eventual consequence that they reach the basement membrane and become spermatogonia (Culty 2009). Gonocytes, preceding the formation of spermatogonia, represent the transient germ cell population with stem cell characteristics in neonatal testes. Like SSCs, gonocytes are able to colonize and produce donorderived spermatogenesis after transplantation into infertile recipient testes (Jiang \& Short 1998, Orwig et al. 2002). In pigs and goats, gonocytes transform to spermatogonia at about 2 months after birth
(Byskov \& Hoyer 1994), while in sheep and cattle, this transition commences at $\sim 3$ and 4 months after birth respectively (Curtis \& Amann 1981, Pedrana et al. 2008, Borjigin et al. 2010, Sarma \& Devi 2012).

The survival and development of SSCs are based on a particular microenvironment termed 'niche' (Scadden 2006). SSCs present in niche strike a balance between self-renewal and differentiation to maintain the consistent spermatogenesis. It has generally been accepted that Sertoli cells, peritubular myoid cells as well as Leydig cells constitute the niche (Kokkinaki et al. 2009, Oatley et al. 2009). Specifically, Sertoli cells, a kind of polorized columnar epithelial cells, offer nutrients for SSCs and differentiating germ cells and mediate intricate signals to support spermatogenesis. Sertoli cells produce glial cell line-derived neurotropic factor (GDNF) and basic fibroblast growth factor (bFGF), both of which are of paramount importance to SSCs self-renewal in vitro (Meng et al. 2000, Hofmann et al. 2005). Peritubular myoid cells and Leydig cells generate colony-stimulating factor 1 (CSF1) which exhibits a synergic effect with GDNF (Oatley et al. 2009). Apart from the ability to 
secrete CSF1, Leydig cells can also stimulate the development of gonad and maintain spermatogenesis via the production of testosterone.

SSCs as a canonical category of stem cells are best characterized by their capability of self-renewal as well as their commitments to the germ line. Recent studies suggest that two functional SSC populations are present in testes: the actual stem cells (SSCs undergoing selfrenewal) and the potential stem cells (a cell population exhibiting the ability to self-renew on condition that they are in adversity) (Brinster \& Zimmermann 1994, Yoshida 2012). When SSCs experience a vast amount of loss under adverse conditions (e.g. exposure to toxicants or chemical agents, physical impairments), the progenitor cells committed to differentiation may act as potential stem cells and resume self-renewal. Consequently, selfrenewal of the whole spermatogonial population tends to outweigh their differentiation, eventually resulting in the recovery of the actual SSCs (Martin \& Seandel 2013). Nevertheless, this proposition of actual and potential stem cells is still heavily debated and is a subject of further studies (de Rooij \& Griswold 2012).

SSCs not only share some identities with other stem cells but also hold their distinct characteristics. Of most uniqueness is that SSCs are the adult stem cells that could transmit genetic information from the paternal generation to the descendants (Brinster 2002, Hamra et al. 2004). Therefore, SSCs are of particular utility in animal genetics, breeding, and reproduction, provided that gene transfection and homologous transplantation of SSCs are synthesized to produce transgenic animals with improved productivity and commercial value. In addition, SSCs provide an ideal model to unravel the mechanisms for stem cell self-renewal and differentiation.

\section{Characterization of spermatogonia in domestic animals}

It is a standard practise to characterize SSCs before subsequent culture, transplantation, or manipulation of the cells. Increasing knowledge has been acquired regarding the molecular markers expressed in murine SSCs (e.g. Itga6, Itgb1, Gfra1, Thy1, Cd9, Cdh1, Lin28, Gpr125, Zbtb16 (Plzf), Pou5f1 (Oct4), Id4, and Nanos2; Shinohara et al. 1999, Kubota et al. 2003, Buaas et al. 2004, Costoya et al. 2004, Kanatsu-Shinohara et al. 2004, Ohmura et al. 2004, Buageaw et al. 2005, Seandel et al. 2007, Tokuda et al. 2007, Zheng et al. 2009, Oatley et al. 2011, Sada et al. 2012). Notably, the proteins identified generally mark (undifferentiated) spermatogonia and are by no means specific for SSCs in rodents. It is also applicable to their domestic counterparts. Yet, Inhibitor of DNA binding 4 (Id4) is recently identified as a marker for putative SSCs in mice due to its specific expression in single spermatogonia, which is undoubtedly a milestone in SSC characterization (Oatley et al. 2011). In comparison, the known phenotypic markers of spermatogonia in domestic animals are relatively limited. Despite the rarity, a few markers have been found to be consistently expressed in spermatogonia from domestic species (Table 1). An illustration of this point is ubiquitin carboxyl-terminal hydrolase L1 (UCHL1). UCHL1, also known as PGP9.5, is first shown to be expressed by mouse spermatogonia (Kon et al. 1999). We and others found the expression of UCHL 1 in prepubertal testes from pigs, cattle, buffalo, and goats (Luo et al. 2006, 2009, Herrid et al. 2007, Goel et al. 2010, Fujihara et al. 2011, Heidari et al. 2012, Zheng et al. 2013a). UCHL1 is expressed in premeiotic male germ cells and does not show an affinity for somatic cells, which makes it an optimal marker for spermatogonia in domestic testes. Similarly, promyelocytic leukemia zinc-finger protein (PLZF, also known as ZBTB16), a transcription factor essential for the maintenance and self-renewal of SSCs, is initially found to be expressed by mouse undifferentiated spermatogonia (Buaas et al. 2004, Costoya et al. 2004). Later, its expression in a sub-population of gonocytes and SSCs/progenitors in pigs, cattle, sheep, goats, and equids is verified (Luo et al. 2006, Borjigin et al. 2010, Reding et al. 2010, Costa et al. 2012, Song et al. 2013, Zheng et al. 2013a).

Unlike UCHL1 and PLZF, lectin Dolichos biflorus agglutinin $(D B A)$ is not expressed in murine germ cells. Moreover, the expression of $D B A$ does not show consistency in domestic species. In boars, DBA only marks primitive germ cells, i.e. gonocytes and primitive spermatogonia, and DBA binding to male germ cells is progressively lost with age (Goel et al. 2007). By comparison, $D B A$ is demonstrated to be expressed in gonocytes and type A spermatogonia from prepubertal bovine and buffalo testes, with an expression profile similar to UCHL1 (Ertl \& Wrobel 1992, Herrid et al. 2007, Goel et al. 2010, 2011, Fujihara et al. 2011). Nonetheless, the expression of $D B A$ is not discerned in germ cells at any stage of ovine development (Borjigin et al. 2010). Thus, even though DBA could be adopted to characterize gonocytes and spermatogonia from some large animals, this is not the case in sheep.

In addition to the aforementioned three markers typically used to identify spermatogonia in domestic animals, some markers of undifferentiated spermatogonia in murine are conserved among species. THY1 (previously known as CD90), for example, is first utilized as a surface marker of undifferentiated spermatogonia in rodents, humans, and nonhuman primates (Kubota et al. 2003, Ryu et al. 2004, Hermann et al. 2009, He et al. 2010). Reding et al. and our group demonstrated the expression of THY1 in gonocytes and undifferentiated spermatogonia from cattle and pigs (Reding et al. 2010, Zheng et al. 2013a) respectively. Recently, both Abbasi et al. (2013) and Wu et al. (2013) have reported the expression of THY1 in undifferentiated spermatogonia 
Table 1 Molecular markers of spermatogonia in testes of domestic animals.

\begin{tabular}{|c|c|c|c|c|}
\hline Marker & References & Species & Approaches & $\begin{array}{l}\text { Expressed in gonocytes or } \\
\text { spermatogonia }\end{array}$ \\
\hline \multirow{6}{*}{ UCHL1 (PGP9.5) } & Luo et al. (2006) & Pig & $\mathrm{IHC}+\mathrm{ICC}$ & Gonocytes and spermatogonia \\
\hline & Herrid et al. (2007) & Cattle & $\mathrm{IHC}+\mathrm{ICC}$ & Gonocytes and spermatogonia \\
\hline & Luo et al. (2009) & Pig & $\mathrm{IHC}+\mathrm{ICC}$ & Gonocytes and spermatogonia \\
\hline & Goel et al. (2010) & Buffalo & $\mathrm{IHC}+\mathrm{ICC}$ & Prepubertal spermatogonia \\
\hline & Fujihara et al. (2011) & Cattle & $\mathrm{IHC}+\mathrm{ICC}+\mathrm{WB}$ & Gonocytes and spermatogonia \\
\hline & Heidari et al. (2012) & Goat & $\mathrm{IHC}+\mathrm{ICC}$ & Gonocytes \\
\hline \multirow[t]{5}{*}{ ZBTB16 } & Luo et al. (2006) & Pig & $\mathrm{IHC}+\mathrm{ICC}$ & Gonocytes and spermatogonia \\
\hline & Borjigin et al. (2010) & Sheep & $\mathrm{IHC}+\mathrm{ICC}$ & Gonocytes and spermatogonia \\
\hline & Reding et al. (2010) & Cattle & $\mathrm{IHC}+\mathrm{ICC}+\mathrm{qPCR}+\mathrm{WB}$ & Gonocytes and spermatogonia \\
\hline & Song et al. (2013) & Goat & $\mathrm{IHC}+\mathrm{ICC}+\mathrm{qPCR}$ & Gonocytes and spermatogonia \\
\hline & Costa et al. (2012) & Equid & $\mathrm{IHC}+\mathrm{WB}$ & Spermatogonia \\
\hline \multirow[t]{6}{*}{$D B A$} & Goel et al. (2007) & Pig & $\mathrm{IHC}+\mathrm{ICC}$ & $\begin{array}{l}\text { Gonocytes (staining weak/absent in } \\
\text { spermatogonia) }\end{array}$ \\
\hline & Ertl \& Wrobel (1992) & Cattle & $\mathrm{IHC}$ & Gonocytes and spermatogonia \\
\hline & Herrid et al. (2007) & Cattle & $\mathrm{IHC}+\mathrm{ICC}$ & Gonocytes and spermatogonia \\
\hline & Goel et al. (2010) & Buffalo & $\mathrm{IHC}+\mathrm{ICC}$ & Prepubertal spermatogonia \\
\hline & Fujihara et al. (2011) & Cattle & $\mathrm{IHC}+\mathrm{ICC}+$ XenoTP & Gonocytes and spermatogonia \\
\hline & Borjigin et al. (2010) & Sheep & $\mathrm{IHC}$ & No expression detected \\
\hline \multirow[t]{4}{*}{ THY1 (CD90) } & Reding et al. (2010) & Cattle & $\begin{array}{c}\text { FACS + MACS + IHC + ICC }+ \\
\text { qPCR + WB + XenoTP }\end{array}$ & Gonocytes and spermatogonia \\
\hline & Zheng et al. (2013a) & Pig & $\begin{array}{l}\text { MACS + IHC + ICC + qPCR } \\
\quad+\text { WB }\end{array}$ & Gonocytes and spermatogonia \\
\hline & Abbasi et al. (2013) & Goat & $\begin{array}{l}\text { MACS + IHC }+ \text { ICC + qPCR }+ \\
\text { WB + XenoTP }\end{array}$ & Spermatogonia \\
\hline & Wu et al. (2013) & Goat & $\mathrm{MACS}+\mathrm{IHC}+\mathrm{ICC}+\mathrm{qPCR}$ & Spermatogonia \\
\hline \multirow[t]{2}{*}{ GFR $\alpha 1$} & Lee et al. (2013) & Pig & MACS + IHC+ICC & Gonocytes \\
\hline & Costa et al. (2012) & Equid & $\mathrm{IHC}+\mathrm{WB}$ & Spermatogonia \\
\hline \multirow[t]{2}{*}{ NANOG2 } & Goel et al. (2008) & Pig & $\mathrm{IHC}$ & $\begin{array}{l}\text { Gonocytes in neonatal testes, } \\
\text { differentiated germ cells, and } \\
\text { undifferentiated spermatogonia } \\
\text { (rare) in prepubertal testes }\end{array}$ \\
\hline & Fujihara et al. (2011) & Cattle & $\mathrm{IHC}+\mathrm{ICC}+\mathrm{WB}$ & $\begin{array}{l}\text { Gonocytes in neonatal testes, } \\
\text { differentiated spermatic cells, and } \\
\text { spermatogonia (rare) in adult testes }\end{array}$ \\
\hline \multirow[t]{4}{*}{ POU5F1 } & Goel et al. (2008) & Pig & $\mathrm{IHC}$ & $\begin{array}{l}\text { Differentiated germ cells and } \\
\text { undifferentiated spermatogonia } \\
\text { (rare) in prepubertal testes }\end{array}$ \\
\hline & Goel et al. (2010) & Buffalo & $\mathrm{IHC}+\mathrm{ICC}$ & Spermatogonia \\
\hline & Fujihara et al. (2011) & Cattle & $\mathrm{IHC}+\mathrm{ICC}+\mathrm{WB}$ & $\begin{array}{l}\text { Gonocytes in neonatal testes, } \\
\text { differentiated spermatic cells, and } \\
\text { spermatogonia (rare) in adult testes }\end{array}$ \\
\hline & Mahla et al. (2012) & Buffalo & $\mathrm{IHC}+\mathrm{ICC}+\mathrm{WB}$ & $\begin{array}{l}\text { Gonocytes and spermatogonia } \\
\text { in prepubertal testes, round } \\
\text { spermatids in adult testes }\end{array}$ \\
\hline SSEA1 & Kim et al. (2013) & Pig & FACS + IHC + ICC + XenoTP & Spermatogonia \\
\hline Claudin-8 & McMillan et al. (2013) & Cattle & $\begin{array}{l}\text { FACS + MACS + IHC + ICC }+ \\
\quad \text { qPCR }\end{array}$ & Spermatogonia \\
\hline CSF1R & Costa et al. (2012) & Equid & $\mathrm{IHC}+\mathrm{WB}$ & Spermatogonia \\
\hline
\end{tabular}

IHC, immunohistochemistry; ICC, immunocytochemistry; WB, western blot; qPCR, quantitative real-time PCR; XenoTP, xenotransplantation; FACS, fluorescence-activated cell sorting; MACS, magnetic-activated cell sorting.

from goat testes, further corroborating that THY1 is a conserved surface marker among species. GDNF family receptor $\alpha 1$ (Gfr $\alpha 1)$ has long been proposed as a surface marker for undifferentiated spermatogonia in mouse testes (Buageaw et al. 2005), and recently its expression in a sub-population of gonocytes in neonatal porcine testes has been reported (Lee et al. 2013). Not surprisingly, undifferentiated spermatogonia with SSC potential are shown to share some phenotypes with embryonic stem (ES) cells. Stage-specific embryonic antigen-1 (SSEA 1) specifically marks a subset of undifferentiated spermatogonia in prepubertal boars
(Kim et al. 2013), and the positive staining of Claudin-8 is discernible in putative SSCs and a handful of Sertoli cells in bovine testes (McMillan et al. 2013). Nevertheless, transcription factors, NANOG and OCT3/4, which are related to the pluripotency of stem cells, seem to be conserved but are less dependable markers for undifferentiated spermatogonia from domestic species, due to the dynamic changes in their expression during germ cell development (Goel et al. 2008, 2010, 2011, Fujihara et al. 2011, Mahla et al. 2012; Table 1).

Despite the accomplishments of spermatogonial characterization, no specific marker for SSCs is currently 
available. Specifically, even though differentiating germ cells express a different set of markers, such as C-Kit, Stra8, and Smc6 (Yoshinaga et al. 1991, Giuili et al. 2002, Verver et al. 2013), the known molecular markers mentioned earlier are usually expressed by SSCs and undifferentiated spermatogonia that are phenotypically identical to the stem cells, but have committed to differentiation and are thought to have lost stem cell activity to some extent. Furthermore, some markers can be expressed in somatic cells as well. As a matter of fact, germ cell transplantation is presently perceived as the only approach to distinguishing between functional stem cells and other spermatogenic subtypes. In this sense, the identification of a unique marker for SSCs, which remains a challenge for researchers in this field, will greatly facilitate the studies of SSCs. In addition, the knowledge of biological markers for SSCs/progenitors in domestic species needs to be expanded.

\section{Isolation and enrichment of spermatogonia from domestic animals}

In adult mice, only $0.02-0.03 \%$ of the total germ cells have stem cell capacity (Tegelenbosch \& de Rooij 1993). Likewise, SSCs are extremely limited in testes from domestic animals. As a consequence, it is necessary to isolate and enrich SSCs with high viability and purity, for the sake of subsequent culture or manipulation of these cells. The development of characterization of spermatogonia lays the foundation for following enrichment, in that some biological markers have the potential to make a difference in this process when using fluorescenceactivated cell sorting (FACS) or magnetic-activated cell sorting (MACS). Apart from the two approaches referring to the phenotype of spermatogonia, physical methodology such as differential plating, the selection with extracellular matrix (ECM), velocity sedimentation, or density gradient centrifugation equally serves as common practise to enrich spermatogonia.

Herrid et al. (2009a) utilized several approaches to obtaining enriched spermatogonia from bovine testes, and found that the combination of enrichment techniques may significantly augment the purity of spermatogonia. Uniformly, both Izadyar et al. (2002) and Goel et al. (2010) combined differential plating with Percoll centrifugation to enhance the purity of type A spermatogonia, with results of over 70 and $55 \%$ in prepubertal cattle and buffalo respectively. The highest purity (90\%) of type A spermatogonia from buffalo testes is achieved by Ahmad et al. (2013), who adopted the selection with ECM (laminin and gelatin) followed by Percoll gradient separation. In sheep, Borjigin et al. (2010) evaluated the enrichment efficiency of differential plating and revealed that the maturity of testes is an important element of spermatogonia recovery. Zhu et al. (2012) found that fibronectin and laminin are optimum ECM for the enrichment of spermatogonia from dairy goats. In boars, even though the efficiency of purification varies with several different methods (Luo et al. 2006, Goel et al. 2007, Kim et al. 2010, 2013, Yang et al. 2010, Yang \& Honaramooz 2011, Zheng et al. 2013a), neonatal gonocytes with as high as $90 \%$ of purity are obtained via Nycodenz centrifugation followed by differential plating (Yang \& Honaramooz 2011).

FACS, which involves the molecular signature of cells, is exploited to enrich spermatogonia from large animals. FACS of SSEA $1^{+}$fraction leads to a markedly enriched population of undifferentiated spermatogonia from pigs (Kim et al. 2013), whereas FACS yields a fourfold rise in $\mathrm{DBA}^{+}$cells from cattle (Herrid et al. 2009a). Like FACS, MACS can be used to enrich spermatogonia, and now it is becoming increasingly prevalent in the isolation and enrichment of spermatogonia from domestic testes. Reding et al. (2010) adopted MACS to enrich undifferentiated spermatogonia in prepubertal bovine testes, resulting in a $\mathrm{THY}^{+}{ }^{+}$fraction composed of $64.4 \%$ of $\mathrm{PLZF}^{+}$cells. Similarly, our group demonstrated that a cell population comprising $55 \%$ of $\mathrm{UCHL}^{+}$cells could be obtained by MACS of THY $1^{+}$cells from neonatal piglets (Zheng et al. 2013a). In goats, MACS of THY1 ${ }^{+}$ cells contributes to a significant enrichment of undifferentiated spermatogonia (Abbasi et al. 2013, Wu et al. 2013). Reports concerning the utilization of MACS and other surface markers to enrich bovine spermatogonia are also available (Herrid et al. 2009a, McMillan et al. 2013). Conclusively, MACS is of inherent advantage in comparison with other approaches. For one thing, MACS is not time-consuming and is easy to reproduce; therefore, this technique could be readily implemented without the requirement for abundant experience. For another, MACS does not require a multitude of cells, but does select the cells with high viability, which is important for subsequent culture or manipulation of SSCs. Also, MACS can easily be scaled to accommodate larger cell numbers of crude single-cell suspensions, while with FACS, sorting time increases dramatically with higher cell input. Given the strengths, MACS is believed to play increasingly vital roles in the isolation and enrichment of spermatogonia from domestic animals.

Of note, it is wrong to equate the enrichment of spermatogonia with that of SSCs. In other words, the enrichment is usually for (undifferentiated) spermatogonia but not necessarily for SSCs. Owing to the absence of a specific marker for SSCs, it is only when transplantation assay is performed that the enrichment of SSCs can be quantified.

\section{In vitro culture of SSCs from domestic animals}

In vitro culture of SSCs is an essential tool to expand and manipulate this rare cell population, and a long-term SSC culture is regarded as a prerequisite for in vitro exploration of SSCs self-renewal and differentiation. 
To date, scientists have succeeded in establishing longterm cultures of SSCs from mice, rats, and hamsters (Kanatsu-Shinohara et al. 2003, 2008, Kubota et al. 2004, Ryu et al. 2005). By contrast, even though researchers have made strenuous efforts to culture SSCs from domestic animals, the propagation of SSCs in vitro could only be maintained for a short time (no longer than 2 months; Aponte et al. 2006, 2008, Luo et al. 2006, Goel et al. 2007, 2009, 2010, Kuijk et al. 2009, Xie et al. 2010, Fujihara et al. 2011, Bahadorani et al. 2012, Heidari et al. 2012, Kala et al. 2012, Nasiri et al. 2012, Zhu et al. 2012, Kadam et al. 2013, Zheng et al. 2013b). As shown in relevant reports, putative SSCs in domestic testes can be isolated and primary cultured with ease, but the proliferation of putative SSCs experiences a gradual decrease during sub-culture, and over time, differentiation and apoptosis dominate the cellular events, with the final consequence that the propagation of SSCs comes to a standstill. SSCs from large animals may hold unique characteristics, since a long-term culture system developed for rodent SSCs could not support the persistent propagation of SSCs from domestic species. It is not unrealistic, however, to establish a longterm culture of SSCs from domestic animals in the near future. To fulfill this goal, three issues need to be taken into account.

First, the culture medium is of overriding importance to the long-term cultivation of SSCs. At present DMEM (high glucose) and DMEM/F12 are the most widely used media in cultures of SSCs from domestic animals (Luo et al. 2006, Goel et al. 2007, 2009, 2010, Xie et al. 2010, Fujihara et al. 2011, Bahadorani et al. 2012, Heidari et al. 2012, Kala et al. 2012, Nasiri et al. 2012, Zhu et al. 2012, Kadam et al. 2013, Zheng et al. 2013b), probably due to the availability and affordability of the media. The corresponding studies, on the other hand, show that DMEM, in all likelihood, promotes both selfrenewal and differentiation of SSCs. StemPro medium, a proprietary product likely to contain unexposed ingredients, is adopted in long-term cultures of SSCs from mice and hamsters (Kanatsu-Shinohara et al. 2003, 2008). Aponte et al. (2008) and Kuijk et al. (2009) reported the application of StemPro medium to in vitro propagation of SSCs from bulls and pigs respectively. However, neither of the aforementioned two media results in the long-term maintenance of SSCs from domestic animals, which leaves room for further improvement in this respect.

Second, it is imperative that appropriate growth factors are included in the culture medium. There is no controversy regarding the use of GDNF for long-term maintenance and self-renewal of murine SSCs during culture. Recently Lee et al. (2013) have reported that Gfra 1 , one of the GDNF family of receptors, is expressed on the surface of gonocytes in boars, showing that GDNF may also play indispensable roles in long-term cultures of SSCs from domestic species. Nevertheless, when culturing SSCs from large animals, the functions of other usually utilized growth factors in rodent SSC culture, such as bFGF, epidermal growth factor (EGF), leukemia inhibitory factor (LIF), and CSF1, if any, remain largely elusive. Indeed, there are inconsistencies in the reports describing the effects of growth factors on the propagation of SSCs from domestic animals (Aponte et al. 2006, 2008, Kuijk et al. 2009, Zhu et al. 2012, Kadam et al. 2013, Zheng et al. 2013b). Even though the conflicting results can sometimes be ascribed to the differences in species or ages of the donors, the ratio of SSCs to contaminating somatic cells at the outset of culture, and even to distinct batches or manufacturers of the growth factors, one fact related to this issue cannot be neglected: it is somewhat imprecise to quantify the cultured SSCs by approaches other than transplantation assay. Currently two approaches are popular in the quantification of the cultured domestic SSCs: SSCderived colony counts and putative SSC (individual cell positive for SSC markers) counts. Both approaches are accompanied by drawbacks. SSC-derived colonies, albeit morphologically distinct from ES-like colonies, are usually aggregates of germ cells and the surrounding somatic cells, and it can be difficult to distinguish some colonies as they are easily covered up by the overwhelming somatic cells. As for the latter, due to the absence of a specific marker for SSCs, positive staining cells at most represent undifferentiated spermatogonia rather than bona fide SSCs, and there is research showing that cultured somatic cells are also able to react positively to a few (undifferentiated) spermatogonia markers (e.g. Uchl1 and Nanog2; Luo et al. 2006, Goel et al. 2009). In a sense, when there is no transplantation performed as a functional assay (Fig. 1), nothing can be said about SSCs. Besides, studies of mechanisms for self-renewal and differentiation of SSCs from domestic species are currently not available. Hence, when propagating SSCs from large animals in vitro, their requirements for specific growth factors as well as their molecular mechanisms for the regulation of self-renewal and differentiation need to be further probed.

Last but not least, serum and feeders are integral parts of a long-term culture of SSCs. Although a feeder- and serum-free culture system for mouse SSCs was established recently (Kanatsu-Shinohara et al. 2011), it is not feasible to cultivate SSCs from domestic animals with neither serum nor feeders. It is noticeable that serum contains undefined components and tends to act as a catalyst for overwhelming somatic cells. In goats and pigs, high concentration of serum has been shown to have a detrimental influence on SSC proliferation (Bahadorani et al. 2012, Zheng et al. 2013b). Therefore, it is sensible to reduce serum in SSC culture. Given the choice, it would be stimulating as well to test alternatives for serum such as knockout serum replacement and B27 supplement, which are artificial and have certain components. In terms of feeders, autologous Sertoli cells 


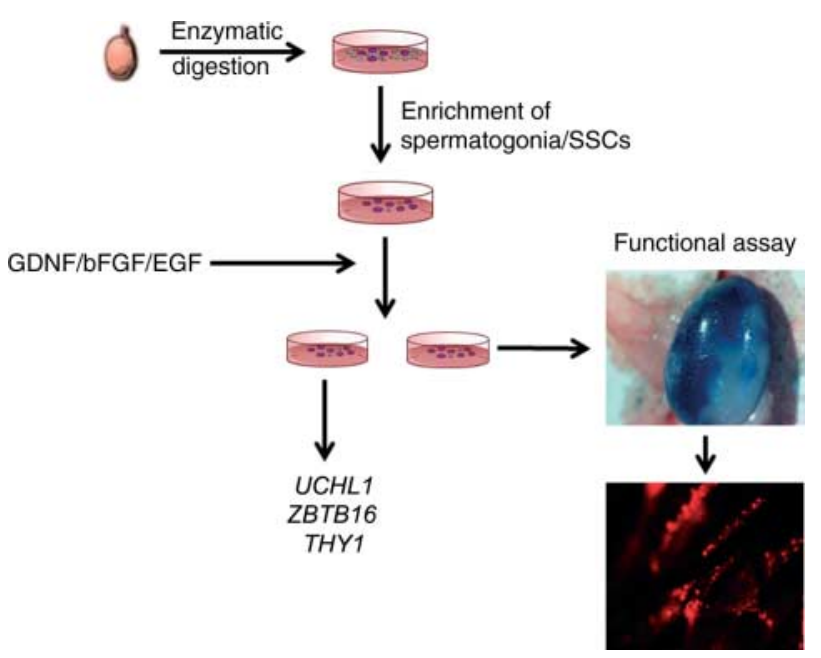

Figure $1 \mathrm{~A}$ schematic representation of procedures involved in enrichment and culture of spermatogonia/SSCs from domestic animals. Donor testis tissue is collected and enzymatically digested to get a single-cell suspension. Spermatogonia/SSCs can be enriched by way of FACS, MACS, or physical methodology (such as differential plating, velocity sedimentation, or density gradient centrifugation).

The enriched spermatogonia/SSCs undergo in vitro propagation in the presence of growth factors (such as GDNF, bFGF, and EGF).

The spermatogonia/SSC identity of the cultured cells is verified by the expression of molecular markers (such as UCHL1, ZBTB16, and THY1) or functional assay. SSCs can survive and colonize in seminiferous tubules of the recipient mouse testes.

are typically used in cultures of SSCs from large species. One drawback of this option is that Sertoli cells are capable of secreting a variety of growth factors, including those committed to SSC differentiation. Nasiri et al. concluded SIM mouse embryo-derived thioguanine and ouabain resistant (STO) that is exploited in long-term cultures of mouse and rat SSCs as a fitting feeder layer to multiply bovine spermatogonia in vitro (Kubota et al. 2004, Ryu et al. 2005, Nasiri et al. 2012). Combing this report with the study which described the substitution of laminin for feeder cells during in vitro propagation of human SSCs (Sadri-Ardekani et al. 2009), it might be preferable to use STO or laminin for longterm cultures of SSCs from domestic testes.

\section{Transplantation of SSCs from domestic animals}

In 1994, Brinster \& Zimmermann (1994) established germ cell transplantation. Since then, this functional assay radically changed the study of SSCs and spermatogenesis because this technique genuinely identifies SSCs in vivo: functional stem cells from donor testes could relocate to the basement membrane provided that they are transplanted into the seminiferous tubules of a host. This report and subsequent studies verified that SSCs from mice or rats could reinitiate spermatogenesis and generate functional sperm after transplantation into recipient mouse testes (Brinster \& Zimmermann 1994, Jiang \& Short 1995, Ogawa et al. 1999). The spectacular discoveries impel scientists to investigate the potential of SSCs from large animals in this respect. As reported, SSCs from domestic species could colonize and proliferate in host mouse testes after transplantation, but could not give rise to entire spermatogenesis (Dobrinski et al. 1999, 2000, Izadyar et al. 2002, Oatley et al. 2002, Kim et al. 2006; Table 2), probably due to the phylogenetic disparity between donors and hosts. Later, allogeneic transplantation of SSCs was tested in boars, bulls, goats, sheep, and dogs (Honaramooz et al. 2002a, 2003, Izadyar et al. 2003, Herrid et al. 2006, 2009b, Kim et al. 2008), and the development of the donor germ cells was observed in those recipients of homogeneous species (Fig. 2A and Table 2).

The desirable testicular xenografting has been developed to become an alternative for germ cell transplantation over the last decade. A breakthrough in this regard was achieved in 2002. Technically, testicular tissue from neonatal piglets and goats was introduced into a host (an immuno-deficient mouse), and viable sperm was attained in this way (Honaramooz et al. $2002 b$; Fig. 2B). From that point onwards, xenografting of testicular tissue from a wide array of domestic animals

Table 2 Summary of germ cell transplantation in different donors of domestic animals and recipient species.

\begin{tabular}{lllccc}
\hline Donor & Recipient & Reference & $\begin{array}{c}\text { Colonization of } \\
\text { SSCs }\end{array}$ & $\begin{array}{c}\text { Donor-derived } \\
\text { spermatozoa }\end{array}$ & Offspring \\
\hline Pig & Mouse & Dobrinski et al. (2000) & + & - & - \\
Pig & Pig & Honaramooz et al. (2002a) & + & + & - \\
Cattle & Mouse & Dobrinski et al. (2000) & + & - & - \\
Cattle & Mouse & Oatley et al. (2002) & + & - & - \\
Cattle & Mouse & Izadyar et al. (2002) & + & - & - \\
Cattle & Cattle & Izadyar et al. (2003) & + & + & - \\
Cattle & Cattle & Herrid et al. (2006) & + & + & + \\
Goat & Goat & Honaramooz et al. (2003) & + & + & + \\
Sheep & Sheep & Herrid et al. (2009b) & + & - & - \\
Horse & Mouse & Dobrinski et al. (2000) & + & - & - \\
Rabbit & Mouse & Dobrinki et al. (1999) & + & - & - \\
Cat & Mouse & Kim et al. (2006) & + & - & - \\
Dog & Mouse & Dobrinski et al. (1999) & + & + & - \\
Dog & Dog & Kim et al. (2008) & + & & - \\
\hline
\end{tabular}

+ , Positive results; - , negative results. 


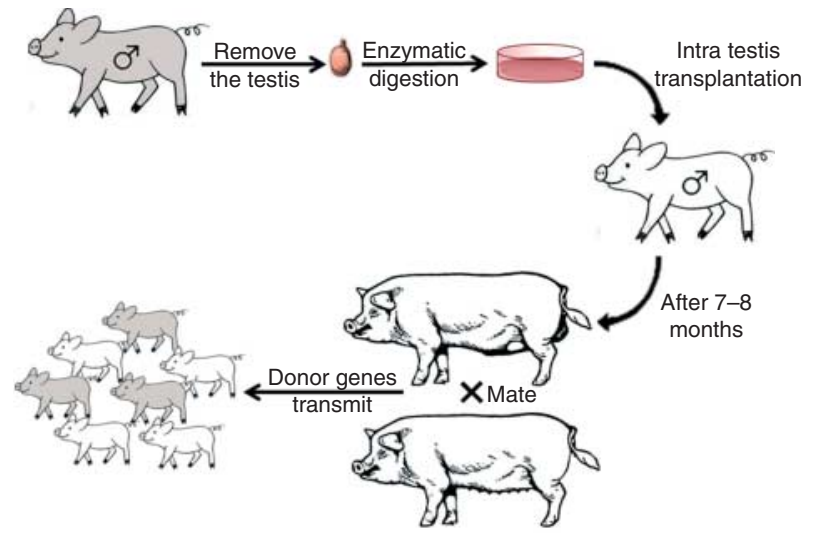

B

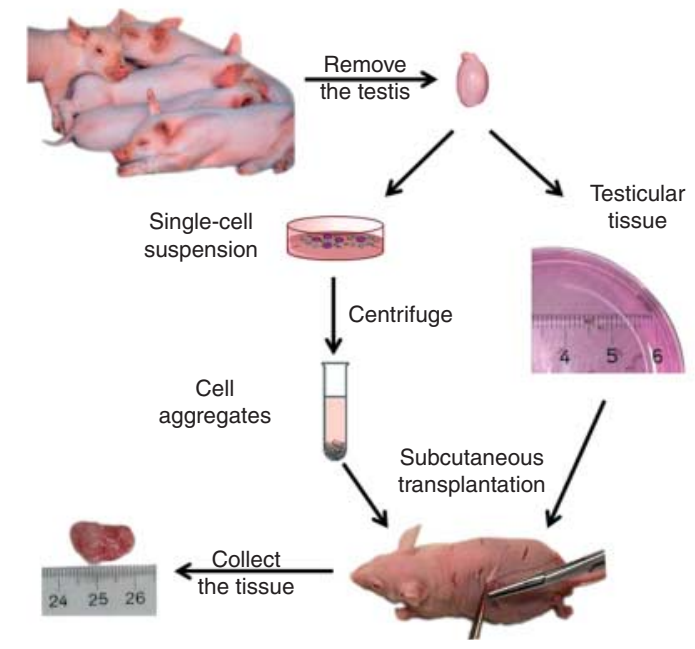

Figure $2 \mathrm{~A}$ schematic representation of procedures involved in transplantation of SSCs from domestic species. (A) Donor testis tissue is collected and enzymatically digested to get a single-cell suspension. Before SSC transplantation, the recipient animals are treated with busulfan or suffer local irradiation of the testes to curtail endogenous SSCs. The transplanted SSCs can form colonies of donor-derived spermatogenesis and produce spermatozoa so as to allow the recipient to sire progeny carrying the donor genes. (B) Testis tissue from donor domestic animals can be cut into small pieces and grafted into the back skin of immuno-deficient mouse. Alternatively, donor testis tissue can be digested into a single-cell suspension. The single-cell suspension is aggregated and transplanted into the back skin of immuno-deficient mouse. The grafted testis tissue or cell aggregates survive and grow up, and even produce donor-derived spermatozoa in the recipient mouse.

including bulls, sheep, horses, and cats has been reported (Oatley et al. 2004, Rathi et al. 2006, Zeng et al. 2006, Kim et al. 2007), with the full spermatogenesis achieved by this means. In 2010, viable piglets were first produced with sperm arising from testicular xenografting (Nakai et al. 2010).

A blockbuster with regard to in vivo study of SSCs might be the emergence of a mighty technique named de novo morphogenesis of testis tissue (Honaramooz et al. 2007). Technically, somatic cells and primitive germ cells from neonatal porcine testes were aggregated and implanted under the dorsal skin of immuno-compromised mouse. After a 4-week period, the transplanted cells reconstructed a spermatogenic unit resembling seminiferous tubules, in which germ cells, Sertoli cells, and interstitial cells were arranged in a way akin to their counterparts in testes. After 30 weeks, elongated spermatids were discernible in the de novo tissue (Fig. 2B). This approach has soon been recapitulated in donor cells from rodents and sheep (Kita et al. 2007, Arregui et al. 2008). Despite that, one major barrier that needs to be removed is the low spermatogenic efficiency $(10-20 \%)$ resulting from this technique (Dores et al. 2012).

\section{Summary}

The fulfillments of SSC characterization, culture, and manipulation in rodents prompt scientists to scrutinize the progressions of their nonrodent counterparts. This review, for this purpose, addresses the recent advances in characterization, isolation, culture, and transplantation of SSCs from domestic animals. The prospects as well as the hindrances that need to be conquered in corresponding fields are also discussed. As SSCs have been consolidating their status as a research focus in reproductive biology and are highly likely to revolutionize the reproductive technology for large animals, our contribution is expected to enable a clear perspective of SSCs in domestic animals, as well as to bridge the gap between their basic research and potential application to animal production.

\section{Declaration of interest}

The authors declare that there is no conflict of interest that could be perceived as prejudicing the impartiality of the review.

\section{Funding}

This work was supported by the National Natural Science Foundation of China (grant numbers 31072029, 31272439, and 31230048), and the Scientific Research Foundation for the Returned Overseas Chinese Scholars from Northwest A\&F University.

\section{Acknowledgements}

The authors thank Dr Zuping He for comments and English language editing.

\section{References}

Abbasi H, Tahmoorespur M, Hosseini SM, Nasiri Z, Bahadorani M, Hajian M, Nasiri MR \& Nasr-Esfahani MH 2013 THY1 as a reliable marker for enrichment of undifferentiated spermatogonia in the goat. Theriogenology 80 923-932. (doi:10.1016/j.theriogenology.2013. 07.020) 
Ahmad S, Xiao Y, Han L, Hua H, Riaz H, Liang A \& Yang LG 2013 Isolation, identification and enrichment of type a spermatogonia from the testis of Chinese cross-bred buffaloes (swamp $\times$ river). Reproduction in Domestic Animals 48 373-381. (doi:10.1111/j.1439-0531.2012.02159.x)

Aponte PM, Soda T, van de Kant HJ \& de Rooij DG 2006 Basic features of bovine spermatogonial culture and effects of glial cell line-derived neurotrophic factor. Theriogenology 65 1828-1847. (doi:10.1016/j. theriogenology.2005.10.020)

Aponte PM, Soda T, Teerds KJ, Mizrak SC, van de Kant HJ \& de Rooij DG 2008 Propagation of bovine spermatogonial stem cells in vitro. Reproduction 136 543-557. (doi:10.1530/REP-07-0419)

Arregui L, Rathi R, Megee SO, Honaramooz A, Gomendio M, Roldan ER \& Dobrinski I 2008 Xenografting of sheep testis tissue and isolated cells as a model for preservation of genetic material from endangered ungulates. Reproduction 136 85-93. (doi:10.1530/REP-07-0433)

Bahadorani M, Hosseini SM, Abedi P, Hajian M, Hosseini SE, Vahdati A, Baharvand H \& Nasr-Esfahani MH 2012 Short-term in-vitro culture of goat enriched spermatogonial stem cells using different serum concentrations. Journal of Assisted Reproduction and Genetics 29 39-46. (doi:10.1007/s10815-011-9687-5)

Borjigin U, Davey R, Hutton K \& Herrid M 2010 Expression of promyelocytic leukaemia zinc-finger in ovine testis and its application in evaluating the enrichment efficiency of differential plating. Reproduction, Fertility, and Development 22 733-742. (doi:10.1071/RD09237)

Brinster RL 2002 Germline stem cell transplantation and transgenesis. Science 296 2174-2176. (doi:10.1126/science.1071607)

Brinster RL \& Zimmermann JW 1994 Spermatogenesis following male germ-cell transplantation. PNAS 91 11298-11302. (doi:10.1073/pnas. 91.24.11298)

Buaas FW, Kirsh AL, Sharma M, McLean DJ, Morris JL, Griswold MD, de Rooij DG \& Braun RE 2004 Plzf is required in adult male germ cells for stem cell self-renewal. Nature Genetics 36 647-652. (doi:10.1038/ng1366)

Buageaw A, Sukhwani M, Ben-Yehudah A, Ehmcke J, Rawe VY, Pholpramool C, Orwig KE \& Schlatt S 2005 GDNF family receptor $\alpha 1$ phenotype of spermatogonial stem cells in immature mouse testes. Biology of Reproduction 73 1011-1016. (doi:10.1095/biolreprod.105.043810)

Byskov AG \& Hoyer PE 1994 Embryology of mammalian gonads and ducts. In The Physiology of Reproduction, edn 5, pp 75-86. Eds E Knobil and JD Neill. New York: Raven Press.

Costa GM, Avelar GF, Rezende-Neto JV, Campos-Junior PH, Lacerda SM, Andrade BS, Thome RG, Hofmann MC \& Franca LR 2012 Spermatogonial stem cell markers and niche in equids. PLOS ONE 7 e44091. (doi:10.1371/journal.pone.0044091)

Costoya JA, Hobbs RM, Barna M, Cattoretti G, Manova K, Sukhwani M, Orwig KE, Wolgemuth DJ \& Pandolfi PP 2004 Essential role of Plzf in maintenance of spermatogonial stem cells. Nature Genetics 36 653-659. (doi:10.1038/ng1367)

Culty M 2009 Gonocytes, the forgotten cells of the germ cell lineage. Birth Defects Research. Part C, Embryo Today: Reviews 87 1-26. (doi:10.1002/ bdrc.20142)

Curtis SK \& Amann RP 1981 Testicular development and establishment of spermatogenesis in Holstein bulls. Journal of Animal Science $\mathbf{5 3}$ 1645-1657.

Dobrinski I, Avarbock MR \& Brinster RL 1999 Transplantation of germ cells from rabbits and dogs into mouse testes. Biology of Reproduction $\mathbf{6 1}$ 1331-1339. (doi:10.1095/biolreprod61.5.1331)

Dobrinski I, Avarbock MR \& Brinster RL 2000 Germ cell transplantation from large domestic animals into mouse testes. Molecular Reproduction and Development 57 270-279. (doi:10.1002/1098-2795(200011) 57:3 <270::AID-MRD9>3.0.CO;2-Z)

Dores C, Alpaugh W \& Dobrinski I 2012 From in vitro culture to in vivo models to study testis development and spermatogenesis. Cell and Tissue Research 349 691-702. (doi:10.1007/s00441-012-1457-x)

Ertl C \& Wrobel KH 1992 Distribution of sugar residues in the bovine testis during postnatal ontogenesis demonstrated with lectin-horseradish peroxidase conjugates. Histochemistry 97 161-171. (doi:10.1007/ BF00267307)

Franca LR, Silva VA Jr, Chiarini-Garcia H, Garcia SK \& Debeljuk L 2000 Cell proliferation and hormonal changes during postnatal development of the testis in the pig. Biology of Reproduction 63 1629-1636. (doi:10.1095/biolreprod63.6.1629)
Fujihara M, Kim SM, Minami N, Yamada M \& Imai H 2011 Characterization and in vitro culture of male germ cells from developing bovine testis. Journal of Reproduction and Development 57 355-364. (doi:10.1262/ jrd.10-185M)

Giuili G, Tomljenovic A, Labrecque N, Oulad-Abdelghani M, Rassoulzadegan M \& Cuzin F 2002 Murine spermatogonial stem cells: targeted transgene expression and purification in an active state. $E M B O$ Reports 3 753-759. (doi:10.1093/embo-reports/kvf149)

Goel S, Sugimoto M, Minami N, Yamada M, Kume S \& Imai H 2007 Identification, isolation, and in vitro culture of porcine gonocytes. Biology of Reproduction 77 127-137. (doi:10.1095/biolreprod.106. 056879)

Goel S, Fujihara M, Minami N, Yamada M \& Imai H 2008 Expression of NANOG, but not POU5F1, points to the stem cell potential of primitive germ cells in neonatal pig testis. Reproduction 135 785-795. (doi:10.1530/REP-07-0476)

Goel S, Fujihara M, Tsuchiya K, Takagi Y, Minami N, Yamada M \& Imai H 2009 Multipotential ability of primitive germ cells from neonatal pig testis cultured in vitro. Reproduction, Fertility, and Development 21 696-708. (doi:10.1071/RD08176)

Goel S, Reddy N, Mandal S, Fujihara M, Kim SM \& Imai H 2010 Spermatogonia-specific proteins expressed in prepubertal buffalo (Bubalus bubalis) testis and their utilization for isolation and in vitro cultivation of spermatogonia. Theriogenology 74 1221-1232. (doi:10. 1016/j.theriogenology.2010.05.025)

Goel S, Reddy N, Mahla RS, Suman SK \& Pawar RM 2011 Spermatogonial stem cells in the testis of an endangered bovid: Indian black buck (Antilope cervicapra L.). Animal Reproduction Science 126 251-257. (doi:10.1016/j.anireprosci.2011.05.012)

Hamra FK, Schultz N, Chapman KM, GrellhesI DM, Cronkhite JT, Hammer RE \& Garbers DL 2004 Defining the spermatogonial stem cell. Developmental Biology 269 393-410. (doi:10.1016/j.ydbio.2004. 01.027)

He Z, Kokkinaki M, Jiang J, Dobrinski I \& Dym M 2010 Isolation, characterization, and culture of human spermatogonia. Biology of Reproduction 82 363-372. (doi:10.1095/biolreprod.109.078550)

Heidari B, Rahmati-Ahmadabadi M, Akhondi MM, Zarnani AH, JeddiTehrani M, Shirazi A, Naderi MM \& Behzadi B 2012 Isolation, identification, and culture of goat spermatogonial stem cells using c-kit and PGP9.5 markers. Journal of Assisted Reproduction and Genetics 29 1029-1038. (doi:10.1007/s10815-012-9828-5)

Hermann BP, Sukhwani M, Simorangkir DR, Chu T, Plant TM \& Orwig KE 2009 Molecular dissection of the male germ cell lineage identifies putative spermatogonial stem cells in rhesus macaques. Human Reproduction 24 1704-1716. (doi:10.1093/humrep/dep073)

Herrid M, Vignarajan S, Davey R, Dobrinski I \& Hill JR 2006 Successful transplantation of bovine testicular cells to heterologous recipients. Reproduction 132 617-624. (doi:10.1530/rep.1.01125)

Herrid M, Davey RJ \& Hill JR 2007 Characterization of germ cells from prepubertal bull calves in preparation for germ cell transplantation. Cell and Tissue Research 330 321-329. (doi:10.1007/s00441-007-0445-z)

Herrid M, Davey RJ, Hutton K, Colditz IG \& Hill JR 2009a A comparison of methods for preparing enriched populations of bovine spermatogonia. Reproduction, Fertility, and Development 21 393-399. (doi:10.1071/ RD08129)

Herrid M, Olejnik J, Jackson M, Suchowerska N, Stockwell S, Davey R, Hutton K, Hope S \& Hill JR 2009b Irradiation enhances the efficiency of testicular germ cell transplantation in sheep. Biology of Reproduction $\mathbf{8 1}$ 898-905. (doi:10.1095/biolreprod.109.078279)

Hofmann MC, Braydich-Stolle L \& Dym M 2005 Isolation of male germ-line stem cells; influence of GDNF. Developmental Biology 279 114-124. (doi:10.1016/j.ydbio.2004.12.006)

Honaramooz A, Megee SO \& Dobrinski I 2002a Germ cell transplantation in pigs. Biology of Reproduction 66 21-28. (doi:10.1095/biolreprod66.1.21)

Honaramooz A, Snedaker A, Boiani M, Scholer H, Dobrinski I \& Schlatt S $2002 b$ Sperm from neonatal mammalian testes grafted in mice. Nature 418 778-781. (doi:10.1038/nature00918)

Honaramooz A, Behboodi E, Megee SO, Overton SA, Galantino-Homer H, Echelard Y \& Dobrinski I 2003 Fertility and germline transmission of donor haplotype following germ cell transplantation in immunocompetent goats. Biology of Reproduction 69 1260-1264. (doi:10. 1095/biolreprod.103.018788) 
Honaramooz A, Megee SO, Rathi R \& Dobrinski I 2007 Building a testis: formation of functional testis tissue after transplantation of isolated porcine (Sus scrofa) testis cells. Biology of Reproduction 76 43-47. (doi:10.1095/biolreprod.106.054999)

Izadyar F, Spierenberg GT, Creemers LB, den Ouden K \& de Rooij DG 2002 Isolation and purification of type A spermatogonia from the bovine testis. Reproduction 124 85-94. (doi:10.1530/rep.0.1240085)

Izadyar F, Den Ouden K, Stout TA, Stout J, Coret J, Lankveld DP, Spoormakers TJ, Colenbrander B, Oldenbroek JK, Van der Ploeg KD et al. 2003 Autologous and homologous transplantation of bovine spermatogonial stem cells. Reproduction 126 765-774. (doi:10.1530/ rep.0.1260765)

Jiang FX \& Short RV 1995 Male germ cell transplantation in rats: apparent synchronization of spermatogenesis between host and donor seminiferous epithelia. International Journal of Andrology 18 326-330. (doi:10. 1111/j.1365-2605.1995.tb00570.x)

Jiang FX \& Short RV 1998 Different fate of primordial germ cells and gonocytes following transplantation. APMIS: Acta Pathologica, Microbiologica, et Immunologica Scandinavica 106 58-62 (discussion 62-63). (doi:10.1111/j.1699-0463.1998.tb01319.x)

Kadam PH, Kala S, Agrawal H, Singh KP, Singh MK, Chauhan MS, Palta P, Singla SK \& Manik RS 2013 Effects of glial cell line-derived neurotrophic factor, fibroblast growth factor 2 and epidermal growth factor on proliferation and the expression of some genes in buffalo (Bubalus bubalis) spermatogonial cells. Reproduction, Fertility, and Development 25 1149-1157. (doi:10.1071/RD12330)

Kala S, Kaushik R, Singh KP, Kadam PH, Singh MK, Manik RS, Singla SK, Palta P \& Chauhan MS 2012 In vitro culture and morphological characterization of prepubertal buffalo (Bubalus bubalis) putative spermatogonial stem cell. Journal of Assisted Reproduction and Genetics 29 1335-1342. (doi:10.1007/s10815-012-9883-y)

Kanatsu-Shinohara M, Ogonuki N, Inoue K, Miki H, Ogura A, Toyokuni S \& Shinohara T 2003 Long-term proliferation in culture and germline transmission of mouse male germline stem cells. Biology of Reproduction 69 612-616. (doi:10.1095/biolreprod.103.017012)

Kanatsu-Shinohara M, Toyokuni S \& Shinohara T 2004 CD9 is a surface marker on mouse and rat male germline stem cells. Biology of Reproduction 70 70-75. (doi:10.1095/biolreprod.103.020867)

Kanatsu-Shinohara M, Muneto T, Lee J, Takenaka M, Chuma S, Nakatsuji N, Horiuchi T \& Shinohara T 2008 Long-term culture of male germline stem cells from hamster testes. Biology of Reproduction 78 611-617. (doi:10.1095/biolreprod.107.065615)

Kanatsu-Shinohara M, Inoue K, Ogonuki N, Morimoto H, Ogura A \& Shinohara T 2011 Serum- and feeder-free culture of mouse germline stem cells. Biology of Reproduction 84 97-105. (doi:10.1095/biolreprod.110. 086462)

Kim Y, Selvaraj V, Dobrinski I, Lee H, McEntee MC \& Travis AJ 2006 Recipient preparation and mixed germ cell isolation for spermatogonial stem cell transplantation in domestic cats. Journal of Andrology 27 248-256. (doi:10.2164/jandrol.05034)

Kim Y, Selvaraj V, Pukazhenthi B \& Travis AJ 2007 Effect of donor age on success of spermatogenesis in feline testis xenografts. Reproduction, Fertility, and Development 19 869-876. (doi:10.1071/RD07056)

Kim Y, Turner D, Nelson J, Dobrinski I, McEntee M \& Travis AJ 2008 Production of donor-derived sperm after spermatogonial stem cell transplantation in the dog. Reproduction 136 823-831. (doi:10.1530/ REP-08-0226)

Kim BG, Cho CM, Lee YA, Kim BJ, Kim KJ, Kim YH, Min KS, Kim CG \& Ryu BY 2010 Enrichment of testicular gonocytes and genetic modification using lentiviral transduction in pigs. Biology of Reproduction $\mathbf{8 2}$ 1162-1169. (doi:10.1095/biolreprod.109.079558)

Kim YH, Kim BJ, Kim BG, Lee YA, Kim KJ, Chung HJ, Hwang S, Woo JS Park JK, Schmidt JA et al. 2013 Stage-specific embryonic antigen-1 expression by undifferentiated spermatogonia in the prepubertal boar testis. Journal of Animal Science 91 3143-3154. (doi:10.2527/jas.2012-6139)

Kita K, Watanabe T, Ohsaka K, Hayashi H, Kubota Y, Nagashima Y, Aoki I, Taniguchi H, Noce T, Inoue K et al. 2007 Production of functional spermatids from mouse germline stem cells in ectopically reconstituted seminiferous tubules. Biology of Reproduction 76 211-217. (doi:10.1095/biolreprod.106.056895)
Kokkinaki M, Lee TL, He Z, Jiang J, Golestaneh N, Hofmann MC, Chan WY \& Dym M 2009 The molecular signature of spermatogonial stem/ progenitor cells in the 6-day-old mouse testis. Biology of Reproduction 80 707-717. (doi:10.1095/biolreprod.108.073809)

Kon Y, Endoh D \& Iwanaga T 1999 Expression of protein gene product 9.5, a neuronal ubiquitin C-terminal hydrolase, and its developing change in Sertoli cells of mouse testis. Molecular Reproduction and Development 54 333-341. (doi:10.1002/(SICI)1098-2795(199912)54:4<333::AIDMRD3 > 3.0.CO;2-8)

Kubota H, Avarbock MR \& Brinster RL 2003 Spermatogonial stem cells share some, but not all, phenotypic and functional characteristics with other stem cells. PNAS 100 6487-6492. (doi:10.1073/pnas. 0631767100)

Kubota H, Avarbock MR \& Brinster RL 2004 Growth factors essential for self-renewal and expansion of mouse spermatogonial stem cells. PNAS 101 16489-16494. (doi:10.1073/pnas.0407063101)

Kuijk EW, Colenbrander B \& Roelen BA 2009 The effects of growth factors on in vitro-cultured porcine testicular cells. Reproduction 138 721-731. (doi:10.1530/REP-09-0138)

Lee K, Lee W, Kim J, Yoon M, Kim N, Kim J, Uhm S, Kim D, Chung H \& Song $\mathbf{H} 2013$ Characterization of GFR $\alpha$-1-positive and GFR $\alpha$-1-negative spermatogonia in neonatal pig testis. Reproduction in Domestic Animals 48 954-960. (doi:10.1111/rda.12193)

Luo J, Megee S, Rathi R \& Dobrinski I 2006 Protein gene product 9.5 is a spermatogonia-specific marker in the pig testis: application to enrichment and culture of porcine spermatogonia. Molecular Reproduction and Development 73 1531-1540. (doi:10.1002/mrd. 20529)

Luo J, Megee S \& Dobrinski I 2009 Asymmetric distribution of UCH-L1 in spermatogonia is associated with maintenance and differentiation of spermatogonial stem cells. Journal of Cellular Physiology 220 460-468. (doi:10.1002/jcp.21789)

Mahla RS, Reddy N \& Goel S 2012 Spermatogonial stem cells (SSCs) in buffalo (Bubalus bubalis) testis. PLOS ONE 7 e36020. (doi:10.1371/ journal.pone.0036020)

Martin LA \& Seandel M 2013 Propagation of adult SSCs: from mouse to human. BioMed Research International 2013 Article ID 384734, 9 pages. (doi:10.1155/2013/384734)

McMillan M, Andronicos N, Davey R, Stockwell S, Hinch G \& Schmoelzl S 2013 Claudin-8 expression in Sertoli cells and putative spermatogonial stem cells in the bovine testis. Reproduction, Fertility, and Development. (doi:10.1071/RD12259)

Meng X, Lindahl M, Hyvonen ME, Parvinen M, de Rooij DG, Hess MW, Raatikainen-Ahokas A, Sainio K, Rauvala H, Lakso M et al. 2000 Regulation of cell fate decision of undifferentiated spermatogonia by GDNF. Science 287 1489-1493. (doi:10.1126/science.287.5457.1489)

Nakai M, Kaneko H, Somfai T, Maedomari N, Ozawa M, Noguchi J, Ito J, Kashiwazaki N \& Kikuchi K 2010 Production of viable piglets for the first time using sperm derived from ectopic testicular xenografts. Reproduction 139 331-335. (doi:10.1530/REP-09-0509)

Nasiri Z, Hosseini SM, Hajian M, Abedi P, Bahadorani M, Baharvand H \& Nasr-Esfahani MH 2012 Effects of different feeder layers on short-term culture of prepubertal bovine testicular germ cells in-vitro. Theriogenology 77 1519-1528. (doi:10.1016/j.theriogenology.2011.11.019)

Oatley JM, de Avila DM, McLean DJ, Griswold MD \& Reeves JJ 2002 Transplantation of bovine germinal cells into mouse testes. Journal of Animal Science 80 1925-1931.

Oatley JM, de Avila DM, Reeves JJ \& McLean DJ 2004 Spermatogenesis and germ cell transgene expression in xenografted bovine testicular tissue. Biology of Reproduction 71 494-501. (doi:10.1095/biolreprod.104. 027953)

Oatley JM, Oatley MJ, Avarbock MR, Tobias JW \& Brinster RL 2009 Colony stimulating factor 1 is an extrinsic stimulator of mouse spermatogonial stem cell self-renewal. Development 136 1191-1199. (doi:10.1242/ dev.032243)

Oatley MJ, Kaucher AV, Racicot KE \& Oatley JM 2011 Inhibitor of DNA binding 4 is expressed selectively by single spermatogonia in the male germline and regulates the self-renewal of spermatogonial stem cells in mice. Biology of Reproduction 85 347-356. (doi:10.1095/biolreprod. 111.091330) 
Ogawa T, Dobrinski I \& Brinster RL 1999 Recipient preparation is critical for spermatogonial transplantation in the rat. Tissue \& Cell 31 461-472. (doi:10.1054/tice.1999.0060)

Ohmura M, Yoshida S, Ide Y, Nagamatsu G, Suda T \& Ohbo K 2004 Spatial analysis of germ stem cell development in Oct-4/EGFP transgenic mice. Archives of Histology and Cytology 67 285-296. (doi:10.1679/aohc. 67.285)

Orwig KE, Ryu BY, Avarbock MR \& Brinster RL 2002 Male germ-line stem cell potential is predicted by morphology of cells in neonatal rat testes. PNAS 99 11706-11711. (doi:10.1073/pnas.182412099)

Pedrana G, Sloboda DM, Perez W, Newnham JP, Bielli A \& Martin GB 2008 Effects of pre-natal glucocorticoids on testicular development in sheep. Anatomia, Histologia, Embryologia 37 352-358. (doi:10.1111/j.14390264.2008.00853.x)

Rathi R, Honaramooz A, Zeng W, Turner R \& Dobrinski I 2006 Germ cell development in equine testis tissue xenografted into mice. Reproduction 131 1091-1098. (doi:10.1530/rep.1.01101)

Reding SC, Stepnoski AL, Cloninger EW \& Oatley JM 2010 THY1 is a conserved marker of undifferentiated spermatogonia in the prepubertal bull testis. Reproduction 139 893-903. (doi:10.1530/REP-090513)

de Rooij DG \& Griswold MD 2012 Questions about spermatogonia posed and answered since 2000. Journal of Andrology 33 1085-1095. (doi:10.2164/jandrol.112.016832)

Ryu BY, Orwig KE, Kubota H, Avarbock MR \& Brinster RL 2004 Phenotypic and functional characteristics of spermatogonial stem cells in rats. Developmental Biology 274 158-170. (doi:10.1016/j.ydbio.2004. 07.004)

Ryu BY, Kubota H, Avarbock MR \& Brinster RL 2005 Conservation of spermatogonial stem cell self-renewal signaling between mouse and rat. PNAS 102 14302-14307. (doi:10.1073/pnas.0506970102)

Sada A, Hasegawa K, Pin PH \& Saga Y 2012 NANOS2 acts downstream of glial cell line-derived neurotrophic factor signaling to suppress differentiation of spermatogonial stem cells. Stem Cells 30 280-291. (doi:10.1002/stem.790)

Sadri-Ardekani H, Mizrak SC, van Daalen SK, Korver CM, RoepersGajadien HL, Koruji M, Hovingh S, de Reijke TM, de la Rosette JJ, van der Veen F et al. 2009 Propagation of human spermatogonial stem cells in vitro. Journal of the American Medical Association 302 2127-2134. (doi:10.1001/jama.2009.1689)

Sarma K \& Devi J 2012 Changes in the seminiferous epithelium of the testes during postnatal development in Assam goat. Anatomy Research International 2012 Article ID 620924, 6 pages. (doi:10.1155/2012/ 620924)

Scadden DT 2006 The stem-cell niche as an entity of action. Nature $\mathbf{4 4 1}$ 1075-1079. (doi:10.1038/nature04957)

Seandel M, James D, Shmelkov SV, Falciatori I, Kim J, Chavala S, Scherr DS, Zhang F, Torres R, Gale NW et al. 2007 Generation of functional multipotent adult stem cells from GPR125+ germline progenitors. Nature 449 346-350. (doi:10.1038/nature06129)

Shinohara T, Avarbock MR \& Brinster RL 1999 B1- and $\alpha 6$-integrin are surface markers on mouse spermatogonial stem cells. PNAS 96 5504-5509. (doi:10.1073/pnas.96.10.5504)

Song W, Zhu H, Li M, Li N, Wu J, Mu H, Yao X, Han W, Liu W \& Hua J 2013 Promyelocytic leukaemia zinc finger maintains self-renewal of male germline stem cells (mGSCs) and its expression pattern in dairy goat testis. Cell Proliferation 46 457-468. (doi:10.1111/cpr.12048)
Tegelenbosch RA \& de Rooij DG 1993 A quantitative study of spermatogonial multiplication and stem cell renewal in the $\mathrm{C} 3 \mathrm{H} / 101$ F1 hybrid mouse. Mutation Research 290 193-200. (doi:10.1016/ 0027-5107(93)90159-D)

Tokuda M, Kadokawa Y, Kurahashi H \& Marunouchi T 2007 CDH1 is a specific marker for undifferentiated spermatogonia in mouse testes. Biology of Reproduction 76 130-141. (doi:10.1095/biolreprod.106.053181)

Verver DE, van Pelt AM, Repping S \& Hamer G 2013 Role for rodent Smc6 in pericentromeric heterochromatin domains during spermatogonial differentiation and meiosis. Cell Death \& Disease 4 e749. (doi:10.1038/ cddis.2013.269)

Wu J, Song W, Zhu H, Niu Z, Mu H, Lei A, Yang C, Peng S, Li X, Li G et al. 2013 Enrichment and characterization of Thy1-positive male germline stem cells (mGSCs) from dairy goat (Capra hircus) testis using magnetic microbeads. Theriogenology 80 1052-1060. (doi:10.1016/ j.theriogenology.2013.08.003)

Xie B, Qin Z, Huang B, Xie T, Yao H, Wei Y, Yang X, Shi D \& Jiang H 2010 In vitro culture and differentiation of buffalo (Bubalus bubalis) spermatogonia. Reproduction in Domestic Animals 45 275-282. (doi:10.1111/j.1439-0531.2008.01281.x)

Yang Y \& Honaramooz A 2011 Efficient purification of neonatal porcine gonocytes with Nycodenz and differential plating. Reproduction, Fertility, and Development 23 496-505. (doi:10.1071/RD10042)

Yang Y, Yarahmadi M \& Honaramooz A 2010 Development of novel strategies for the isolation of piglet testis cells with a high proportion of gonocytes. Reproduction, Fertility, and Development 22 1057-1065. (doi:10.1071/RD09316)

Yoshida S 2012 Elucidating the identity and behavior of spermatogenic stem cells in the mouse testis. Reproduction 144 293-302. (doi:10.1530/ REP-11-0320)

Yoshinaga K, Nishikawa S, Ogawa M, Hayashi S, Kunisada T, Fujimoto T \& Nishikawa S 1991 Role of c-kit in mouse spermatogenesis: identification of spermatogonia as a specific site of c-kit expression and function. Development 113 689-699.

Zeng W, Avelar GF, Rathi R, Franca LR \& Dobrinski I 2006 The length of the spermatogenic cycle is conserved in porcine and ovine testis xenografts. Journal of Andrology 27 527-533. (doi:10.2164/jandrol.05143)

Zheng K, Wu X, Kaestner KH \& Wang PJ 2009 The pluripotency factor LIN28 marks undifferentiated spermatogonia in mouse. BMC Developmental Biology 9 38. (doi:10.1186/1471-213X-9-38)

Zheng Y, He Y, An J, Qin J, Wang Y, Zhang Y, Tian X \& Zeng W 2013a THY1 is a surface marker of porcine gonocytes. Reproduction, Fertility, and Development. (doi:10.1071/RD13075)

Zheng Y, Tian X, Zhang Y, Qin J, An J \& Zeng W 2013b In vitro propagation of male germline stem cells from piglets. Journal of Assisted Reproduction and Genetics 30 945-952. (doi:10.1007/s10815-0130031-0)

Zhu H, Liu C, Li M, Sun J, Song W \& Hua J 2012 Optimization of the conditions of isolation and culture of dairy goat male germline stem cells (mGSC). Animal Reproduction Science 137 45-52. (doi:10.1016/ j.anireprosci.2012.12.005)

Received 19 September 2013

First decision 22 October 2013

Revised manuscript received 11 December 2013

Accepted 19 December 2013 